\title{
Larangan Aktivitas Jemaat Ahmadiyah Indonesia (JAI) di Jawa Timur dalam Perspektif External Protection dan Internal Restriction Will Kymlicka
}

\author{
Aimmatul Alawiyah \\ Center for Marginalized Society Studies (CMARs), Surabaya \\ aimmah.allaits@gmail.com
}

\begin{abstract}
In order to protect Ahmadiyah in East Java, the executive body of East Java Province has issued a Degree No. 188/94/KPTS/013/2011 regarding the prohibition of the Ahmadi's activity in east java. However, it becomes controversial. On one hand, it is considered protecting minority's right, but on the other hand, it also weakens the position of Ahmadiyah toward majority's group outside Ahmadiyah. One implication of the degree is the loss of the primer rights of the group in worshiping their belief in accordance with their faith. Combining Kymlicka's external protection and internal restriction, this article attempts to analyze the implication from the government degree. The basic assumption of this article is that the country is incapable to protect the existence of minority group, Ahmadiyah. The finding shows that the Government of East Java cannot protect the principle rights of Ahmadiyah, especially the right to worship based on their religious belief. As a response to this restriction, Ahmadiyah has applied an internal restriction towards their members that protect themselves from the majority. However, this restriction does not have a penalty so it is considered protecting individual rights of Ahmadiyah group.
\end{abstract}

Keywords: Governor Decree, Ahmadiyah, Internal Restriction, Eksternal Protection, Will Kymlicka. 


\section{Pendahuluan}

Permasalahan terkait Ahmadiyah di Indonesia mengemuka secara nasional sejak terjadinya kekerasan di Cikeusik, Pandeglang, Banten pada awal Februari 2011. ${ }^{1}$ Di tahun yang sama, Gubernur Jawa Timur menerbitkan Surat Keputusan No. 188/94/KPTS/013/2011 yang membatasi aktivitas Jemaat Ahmadiyah Indonesia khususnya di Jawa Timur. SK tersebut menunjukkan kepada khalayak bahwa Negara telah mencederai kebebasan beragama bagi kelompok Ahmadiyah di Jawa Timur. Ahmadiyah secara jumlah maupun peran merupakan kelompok minoritas di Indonesia. Merujuk pada SK tersebut, peraturan di Indonesia mengenai agama lebih cenderung berpihak pada mayoritas dan memberikan kecurigaan besar terhadap kelompok minoritas.

Permasalahan tentang peraturan larangan aktivitas Jemaat Ahmadiyah erat kaitannya dengan UU No.1/PNPS/1965. Sama halnya dengan UU tersebut, SK Gubernur Jawa Timur mengesankan bahwa perlindungan lebih ditujukan pada agama, bukan terhadap pemeluknya. Padahal seharusnya yang dilindungi adalah warga negara, bukan agamanya, karena agama bukanlah subyek hukum. ${ }^{2}$ Permasalahan mendasar dari terbitnya SK Gubernur Jawa Timur adalah pengabaian hak-hak dasar warga negara dalam memilih agama dan beribadah secara bebas. Pengabaian tentang hak-hak dasar tersebut sangat bertolak belakang dengan konstitusi khususnya pada pasal 28E.

Secara umum, negara mempunyai fungsi sebagai alat atau wewenang yang mengatur atau mengendalikan persoalan-persoalan bersama atas nama masyarakat. ${ }^{3}$ Merujuk pada istilah tersebut, negara seharusnya mampu untuk menentukan kebijakan-kebijakan yang menyangkut SARA tanpa ada keberpihakan pada salah satu kelompok. Namun, beberapa regulasi agama yang sudah terbit di Indonesia belum

1 Zainal Abidin Bagir, Telaah Kasus Abmadiyah di Indonesia (Yogyakarta: CRCS Document, 2011).

2 Ahmad Najib Burhani, "Tiga Problem Dasar dalam Perlindungan Agama-Agama Minoritas di Indonesia”, dalam Ma'arif, Vol. III, No.1, 2012.

3 Akmal Salim Ruhana, "Negara Sekuler Mengatur Agama: Studi Pengelolaan Kehidupan Keagamaan di Singapura dan Lesson Learned untuk Indonesia", dalam Dialog, Vol. VII, No.1, 2012. 
mencerminkan kenetralan negara dalam menyikapi permasalahan tentang SARA. Terbukti pada Surat Keputusan Bersama Tiga Menteri (SKB) tahun 2008, negara belum menunjukkan sikap yang bijak terhadap konflik intoleransi mengatasnamakan agama. Bahkan, SKB sering kali dijadikan senjata bagi kelompok mayoritas untuk mempersekusi kelompok minoritas Ahmadiyah.

Selain dari regulasi yang diterbitkan oleh pemerintah, produk hukum non pemerintah juga turut memicu konflik intoleransi terkait kasus Ahmadiyah. Produk hukum tersebut adalah fatwa MUI yang terbit pada tahun 1980 dan 2005. Sejak terbitnya fatwa tentang kesesatan Ahmadiyah, masyarakat seolah mendapat persetujuan untuk menyerang kelompok Ahmadiyah hingga pada puncaknya tiga warga Ahmadi meninggal akibat peristiwa Cikeusik.

Di dalam teorinya tentang hak-hak minoritas, Kymlicka menyebutkan adanya hak perorangan dan hak kolektif, dan menjelaskan tentang dua sistem yang digunakan untuk melindungi hak asasi bagi kelompok minoritas. Dua sistem tersebut ditujukan pada kelompok minoritas namun dalam skala jumlah yang berbeda. Kymlicka menyebut dua sistem tersebut dengan perlindungan eksternal (external protection) dan pembatasan internal (internal restriction). Perlindungan eksternal dimaksudkan untuk melindungi kelompok minoritas dari tekanan luar, misalnya keputusan ekonomi dan politik masyarakat luas. ${ }^{4}$ Sedangkan pembatasan internal dimaksudkan untuk melindungi kelompok kecil dari ketidakstabilan perbedaan pendapat, misalnya keputusan setiap anggota untuk bebas memilih antara mengikuti budaya tradisional atau tidak. ${ }^{5}$ Pembatasan internal juga dimaksudkan agar kelompok minoritas tidak memaksakan pendapat terhadap anggota di dalam kelompoknya. ${ }^{6}$

Untuk dapat menerapkan dua sistem yang disebut Kymlicka sebagai perlindungan eksternal dan pembatasan internal, ia menjelaskan tiga cara yang menurutnya mampu menjaga kestabilan pendapat antar

\footnotetext{
${ }^{4}$ Will Kymlicka, Kewargaan Multikultural, terj. F. Budi Hardiman (Jakarta: LP3ES, 2002), 52.

${ }^{5}$ Ibid.

6 Will Kymlicka and Rubio Marin, "Liberalism and Minority Rights, An Interview", dalam Ratio Juris, Vol.12, No.02 (Cowley Road: Blackwell Publisher Ltd, 1999), 136.
} 
kelompok minoritas maupun intern kelompok minoritas. Tiga cara tersebut adalah hak atas pemerintahan sendiri, hak-hak polietnis, dan hak perwakilan khusus.

Hak atas pemerintahan sendiri mengalihkan kekuasaan ke unit politik yang lebih kecil, sehingga kelompok minoritas tidak dapat dikalahkan dalam pemilihan oleh mayoritas yang berkenaan dengan keputusan sangat penting bagi keberlangsungan kelompoknya. ${ }^{7}$ Hak atas pemerintahan sendiri menurut Kymlicka hanya mampu diterapkan pada kelompok minoritas bangsa yang terkumpul dalam teritorial wilayah tertentu. Contoh dari hak tersebut adalah provinsi Quebec di Kanada.

Hak polietnis melindungi praktik-praktik agama dan budaya yang khas, yang mungkin tidak didukung secara layak oleh pemerintah. ${ }^{8}$ Hak polietnis ini hanya mampu diterapkan pada kelompok etnis yang sering kali dirugikan oleh perundingan yang dibuat oleh khalayak. Tuntutan yang paling kontroversial dari kelompok etnis adalah pengecualian dari konstitusi yang merugikan mereka. ${ }^{9}$ Contoh dari penerapan hak-hak polietnis adalah kaum Yahudi dan Muslim di Inggris, yang telah mengupayakan pengecualian dari konstitusi yang melarang buka usaha di hari Minggu. Contoh lain dari hak polietnis adalah kaum Sikh di Kanada yang telah mengupayakan pengecualian untuk undangundang yang mengharuskan penggunaan helm ketika berkendara sehingga ia tetap menggunakan sorbannya. ${ }^{10}$

Hak perwakilan kelompok khusus di dalam lembaga politik masyarakat yang lebih luas menjadikan kecil kemungkinan bahwa minoritas bangsa atau etnis akan diabaikan dalam keputusan yang dibuat berbasiskan seluruh negeri. ${ }^{11}$ Idealnya, hak ini mampu diterapkan pada tiap kelompok etnis maupun bangsa sehingga dua sistem hak yaitu

\footnotetext{
${ }^{7}$ Raphael Cohen Almagor, Democracy and Multiculturalism, Challenges to Democracy: Essays in Honour and Memory of Isaiah Berlin (London: Ashgate Publishing Ltd, 2000), 100-101.

${ }^{8}$ Kymlicka, Kewargaan Multikultural, 55.

9 Daniel I. O'Neill, Multicultural Liberals and the Rushdie Affair: A Critique of Kymlicka, Taylor, and Walzer, dalam The Review Politics, Vol. 61, No. 02 (Notre Dame: Cambridge University Press, 1999), 225-226.

${ }^{10}$ Kymlicka, Kewargaan Multikultural, 46.

${ }^{11}$ Ibid., 55.
} 
perlindungan eksternal maupun pembatasan internal mampu diterapkan secara maksimal.

\section{Minoritas dan Kebijakan Negara}

Pada 28 Februari tahun 2011, pemerintah Jawa Timur menerbitkan Surat Keputusan yang ditujukan untuk kelompok minoritas Ahmadiyah. Butir-butir yang terdapat dalam SK tersebut berisi tentang larangan aktivitas Jemaat Ahmadiyah khususnya di Jawa Timur yang dianggap memicu atau menyebabkan terganggunya keamanan dan ketertiban masyarakat Jawa Timur. ${ }^{12}$ Secara kronologis, SK ini muncul tidak lama setelah penyerangan terhadap kelompok Ahmadiyah di Cikeusik. Sebelum SK Gubernur ini muncul, pada tahun 2008 Menteri Agama, Menteri dalam Negeri, dan Kejaksaan Agung juga menerbitkan rangkaian aturan yang ditujukan pada Jemaat Ahmadiyah Indonesia (JAI). Aturan tersebut dikenal sebagai Surat Keputusan Bersama (SKB) Tiga Menteri.

Dari segi substansi, dua aturan tersebut memiliki muatan yang sama. Namun, ada satu poin dalam SKB yang tereduksi atau bahkan tidak disebutkan dalam SK Gubernur Jawa Timur, yaitu aturan tentang pemberian peringatan kepada anggota non-JAI untuk menjaga dan memelihara kerukunan umat beragama serta ketenteraman dan ketertiban masyarakat, dengan tidak melakukan perbuatan atau tindakan melawan hukum terhadap kelompok Ahmadiyah. ${ }^{13}$ Pernyataan tersebut tertuang dalam diktum SKB Tiga Menteri. Sedangkan dalam SK Gubernur tidak ada poin yang sama dengan diktum keempat SKB Tiga Menteri tersebut.

Dua peraturan tersebut bersifat paradoksal, karena menempatkan hak warga yang terlanggar menjadi objek pembatasan hukum. Selain itu, dua peraturan tersebut juga terkesan diskriminatif karena peraturan yang memisahkan antara aktivitas keagamaan dengan kenegaraan tidak

12 Keputusan Gubernur Jawa Timur Nomor 188/94/KPTS/013/2011 tentang Larangan Aktivitas Jemaat Ahmadiyah Indonesia (JAI) di Jawa Timur.

13 Keputusan Bersama Menteri Agama, Jaksa Agung, dan Menteri dalam Negeri dalam Negeri Republik Indonesia No.3 Tahun 2008, Kep-033/A/JA/6/2008, No. 199 Tahun 2008. 
diterapkan pada seluruh kelompok agama. Di satu sisi, aturan tersebut dirasa mampu untuk menciptakan ketertiban umum dengan kata lain mampu meredam konflik anti-JAI. Namun, di sisi lain aturan tersebut juga menjadikan kelompok JAI semakin rentan terhadap pengabaian hakhak dasar terkait hak beribadah.

Terbitnya dua aturan tersebut merupakan rekomendasi dari Badan Koordinasi Pengawas Aliran Kepercayaan Masyarakat (Bakor Pakem) yang berlandaskan UU 1/PNPS/1965 tentang Pencegahan Penyalahgunaan dan Penodaan Agama. Kelompok-kelompok Islam arusutama yang dibawahi oleh MUI memfatwakan bahwa aliran Ahmadiyah telah menodai Islam, karena mempercayai adanya Nabi setelah Nabi Muhammad. Terbitnya SKB tentunya melalui proses dialog yang panjang. Dari beberapa dialog yang dilakukan antara JAI dengan unsurunsur lain terpilihlah solusi bahwa Ahmadiyah memilih ingin diterima sebagai kelompok dalam Islam. ${ }^{14}$ Tidak sampai di sini, sebagai konsekuensi atas pilihan tersebut, pemerintah meminta kelompok JAI agar menjelaskan kepada masyarakat tentang posisi keyakinan dan kemasyarakatannya, sehingga pada 14 Januari 2008 PB JAI mengeluarkan 12 butir penjelasan sebagai klarifikasi atas status sesat yang disandangkan oleh kelompok Islam arus-utama terhadap Ahmadiyah. Di dalam 12 butir penjelasan tersebut, Ahmadiyah menekankan bahwa kelompoknya tidak berbeda dengan kelompok Islam arus-utama yang berada di Indonesia. Hanya saja status Mirza Ghulam Ahmad yang diakui Ahmadiyah sebagai guru, mursyid, pembawa kabar gembira, dan pemberi peringatan masih dipertentangkan oleh kelompok Islam arus-utama. Sebagai tanggapan atas status tersebut, MUI memberikan tiga pilihan terhadap Ahmadiyah, yaitu: menyuruh kelompok Ahmadiyah untuk bertobat dan kembali ke jalan yang benar, menjadikan kelompok Ahmadiyah sebagai agama tersendiri, dan pilihan terakhir adalah Ahmadiyah dibubarkan. ${ }^{15}$

Atas dasar rekomendasi dari kelompok-kelompok antiAhmadiyah dan berdasarkan rapat Bakor Pakem yang terakhir pada

\footnotetext{
${ }_{14}$ Akmal Salim Ruhana, Menguji Penanganan Abmadiyah (Jakarta: Gaung Persada Press, 2009), 15-16.

15 Khoirudin Nasution, "Fatwa Majelis Ulama Indonesia (MUI): On Ahmadiyah", dalam Millah Jurnal Studi Agama, Vol. 7, No. 2, 2008, 2.
} 
tanggal 16 April 2008, akhirnya rekomendasi tersebut sampai pada Menteri Agama, Jaksa Agung, dan Menteri dalam Negeri yang pada akhirnya melahirkan SKB Tiga Menteri. SKB tersebut berisi tentang penegasan perintah terhadap pelarangan kegiatan Ahmadiyah. Namun dari keenam butir aturan dalam SKB, tidak sepenuhnya menyudutkan kelompok Ahmadiyah. Terbukti dalam butir keempat dijelaskan bahwa masyarakat non-JAI juga diharapkan agar senantiasa menjaga kehidupan kerukunan antarumat beragama serta tetap menjaga ketertiban dan ketenteraman dalam kehidupan berbangsa dan bernegara. Penegasan terakhir pada SKB juga turut disebutkan sebagai peringatan kepada siapa pun yang melanggar aturan yang sudah disebutkan dalam SKB, baik anggota JAI maupun non-JAI akan dikenakan sanksi sesuai ketentuan peraturan dan perundang-undangan.

SKB inilah yang secara tidak langsung menjadi peluang masuk bagi pemerintah daerah untuk menerbitkan aturan yang senada. Sampai pada tahun 2011 terhitung 5 provinsi dan 22 peraturan Walikota yang sudah terbit terkait peraturan anti-Ahmadiyah. Lima provinsi tersebut diantaranya adalah Jawa Timur, Banten, Jawa Barat, Sumatera Barat, dan Sulawesi Selatan. ${ }^{16}$

\section{Menyoal Bentuk Perlindungan terhadap Minoritas dalam SK Gubernur No.188/94/KPTS/2011}

Setelah dialog yang melahirkan SKB diadakan pada rentang tahun 2007-2008, pemerintah pusat untuk kedua kalinya mengajak Jemaat Ahmadiyah Indonesia berdialog guna merumuskan solusi untuk Ahmadiyah. Niat baik tersebut agaknya tidak disambut dengan baik oleh PB JAI yaitu Abdul Basit. Ia menganggap bahwa peserta dialog tidak netral, sehingga mengurungkan niatnya untuk berpartisipasi dalam dialog tersebut. Selain JAI, pemerintah juga mengundang perwakilan LSM, kalangan akademisi, ormas Islam, MUI, Badan Intelijen Negara, Polri,

\footnotetext{
16 Human Right Watch, Atas Nama Agama: Pelanggaran terhadap Minoritas Agama di Indonesia (USA: Human Right Watch, 2013), 37; Kontras, Pelanggaran HAM dan Pelanggaran HAM Berat dalam Kasus-Kasus Kebebasan Beragama Berkeyakinan dan Beribadah di Indonesia, 11-12.
} 
Kejaksaan Agung, dan beberapa perwakilan daerah yang juga memberlakukan peraturan daerah terkait Ahmadiyah. Dialog tersebut mulanya berencana untuk mengeluarkan keputusan baru menyangkut nasib JAI. Namun, pada akhir April 2011 belum ada pengumuman resmi tentang keputusan dialog tersebut. ${ }^{17}$

Hingga SK Gubernur diterbitkan, Ahmadiyah merasa tidak pernah dimintai pendapat atau bahkan klarifikasi terkait kesesatan oleh kelompok Islam arus-utama. Bahkan, pemerintah tidak pernah menjelaskan tentang kegiatan Ahmadiyah yang dianggap memicu gangguan ketertiban umum sehingga terbit Surat Keputusan tersebut. ${ }^{18}$ Ahmadiyah menganggap bahwa materi SK Gubernur masih multitafsir. Beberapa poin dalam SK tersebut tidak pernah disosialisasikan secara utuh kepada masyarakat. Poin penekanan hanya pada pelarangan terhadap segala kegiatan Ahmadiyah yang dianggap mampu memicu gangguan ketertiban umum. Pemahaman yang tidak utuh tersebut, spontan menimbulkan aksi kelompok Islam arus-utama untuk mempersekusi kelompok Ahmadiyah sehingga diskriminasi terhadap kelompok minoritas Ahmadiyah secara tajam.

Dalam beberapa kasus Ahmadiyah, pemerintah daerah telah memfasilitasi pertemuan antara kelompok mayoritas dengan minoritas. Namun, sering kali kesempatan tersebut bukan untuk menemukan solusi yang seimbang melainkan semakin memberi ruang pada mayoritas untuk menekan kelompok minoritas. Pada tahap akhir, pemerintah baik pusat maupun daerah mengeluarkan peraturan atau kebijakan yang cenderung menyuarakan mayoritas. Hal ini terjadi pada kelompok Ahmadiyah di beberapa daerah termasuk Jawa Timur. Peraturan ini lagi-lagi dijadikan alat legitimasi bagi mayoritas dalam melakukan tindakan pelanggaran kebebasan beragama.

Dari beberapa penelitian yang telah dicatat oleh LSM, sebagian besar pelanggaran dilakukan oleh aktor non-negara. Aktor non-negara terdiri atas individu maupun kelompok masyarakat yang tergabung dalam

\footnotetext{
17 Munarman: Ahmadiyah Adu Domba Pemerintah, http://www.suaraislam.com/read/index/2223/Munarman--Ahmadiyah-Adu-Domba-Pemerintah/ diakses 15 Juli 2015.

${ }^{18}$ Basuki, Wawancara, Surabaya, 18 Juni 2015.
} 
organisasi-organisasi kemasyarakatan. ${ }^{19}$ Salah satu dari organisasi kemasyarakatan tersebut adalah MUI. MUI sering kali mengeluarkan fatwa yang turut memprovokasi terjadinya tindak intoleransi di beberapa daerah. Suatu contoh adalah fatwa MUI tentang kesesatan Ahmadiyah pada tahun 1980 dan 2005 yang pada akhirnya menimbulkan rentetan kekerasan terhadap penganut kelompok Ahmadiyah di beberapa daerah. Penyerangan terhadap masjid-masjid Ahmadiyah kerap terjadi setelah keluarnya fatwa MUI, seperti perusakan masjid di Cenae, Wajo, Sulawesi Selatan tahun 2005, demo dan perusakan kampus Mubarak, Parung, Bogor tahun 2005, perusakan gedung pertemuan milik kaum Ibu JAI di Parung, Bogor tahun 2005, perusakan masjid JAI di Ciareteun, Bogor tahun 2005, penyegelan masjid dan musala di Manislor tahun 2005, perusakan masjid dan rumah anggota di Cijati, Cianjur tahun $2005 .{ }^{20}$

Fatwa yang dikeluarkan oleh MUI kerap mendapat kritikan dari berbagai pihak. Dari kalangan ulama' NU, salah satu PBNU yaitu Masdar Farid Mas'udi menghimbau agar MUI mencabut fatwa yang berkaitan dengan Ahmadiyah karena dikhawatirkan dapat memicu meluasnya kekerasan yang mengatasnamakan agama. ${ }^{21}$ Idealnya, apabila fatwa sudah menjadi bahan rujukan bagi masyarakat, maka fatwa harus berpedoman pada kemaslahatan umat, terlepas dari apakah umat tersebut mayoritas ataupun minoritas. Ironisnya, fatwa MUI bahkan menjadi alat legitimasi bagi kelompok anti-Ahmadiyah untuk ber-legal jihad. Selain itu, fatwa MUI juga turut mempengaruhi penerbitan peraturan-peraturan maupun kebijakan pemerintah daerah dengan tujuan untuk meredam konflik yang telah disulut oleh beberapa organisasi ataupun kelompok antiAhmadiyah.

Para pelaku pelanggaran lainnya baik secara langsung maupun tidak langsung adalah aktor negara. Negara tidak hanya lemah dan lalai dalam melindungi kelompok minoritas, tetapi juga menjadi pelaku

19 The Wahid Institute, Laporan Tabunan Kebebasan Beragama/Berkeyakinan dan Intoleransi 2014: Utang Warisan Pemerintahan Baru, 2014.

20 Munawar Ahmad dan Candy's Bowl, Politik Kerukunan Umat Beragama di Indonesia (Yogyakarta: Suka Press, 2013), 13.

${ }_{21}$ MUI Telah Jadi Inspirator Tindakan Kekerasan, http://www.nu.or.id/ diakses 17 Juni 2015. 
pelanggaran dengan memberlakukan pembatasan kebebasan beragama melalui peraturan baik pusat maupun daerah. ${ }^{22}$ Beberapa kebijakan pemerintah baik pusat maupun daerah terkait minoritas Ahmadiyah secara tidak langsung menjadikan alat legitimasi bagi kelompok antiAhmadiyah sebagai upaya untuk mendiskriminasi Ahmadiyah di beberapa daerah termasuk Jawa Timur. Sementara itu, aparat pemerintah bersama-sama dengan polisi dan pemerintah setempat merupakan pelaku pelanggaran atas nama kebebasan beragama. Bentuk pelanggaran bisa berupa pembiaran pelanggaran, diskriminasi dan penyegelan tempat ibadah. Pemerintah setempat sepertinya enggan untuk berhadapan dengan kelompok minoritas. Lebih-lebih pemerintah daerah tampaknya khawatir jika mereka dianggap tidak membela agama yang benar. ${ }^{23}$

Surat Keputusan Gubernur yang lahir karena alasan kerusuhan di beberapa daerah, menuai banyak kontroversi. Surat tertanggal 28 Februari 2011 yang disahkan oleh Gubernur Jawa Timur mengundang protes dari aktivis hak asasi manusia. Protes muncul dari Jaringan Masyarakat Anti-Kekerasan (JAMAK) dan Aliansi Anak Bangsa Peduli HAM. Menurut Presidium JAMAK, Surat Keputusan tersebut lebih layak ditujukan pada masyarakat yang melakukan kekerasan terhadap Ahmadiyah. ${ }^{24}$ Pemerintah yang cenderung mendukung pendapat kelompok mayoritas mengesankan bahwa pemerintah masih segan dengan mayoritas masyarakat anti-Ahmadiyah.

Selain JAMAK dan Aliansi Anak Bangsa Peduli HAM, Koalisi Masyarakat Sipil dan Kewarganegaraan juga melayangkan protes terhadap pemerintah Jawa Timur. Mereka menganggap bahwa penerbitan SK Anti-Ahmadiyah telah melanggar hak kebebasan warga negara untuk beribadah dan memeluk agama. ${ }^{25}$ Mereka menilai bahwa pemerintah masih mengakomodasi secara politik kelompok penentang

\footnotetext{
22 The Wahid Institute, Laporan Tabunan Kebebasan Beragama/Berkeyakinan dan Intoleransi 2014: Utang Warisan Pemerintah Baru (Jakarta: The Wahid Institute, 2014)

${ }^{23}$ Ibid.

${ }^{24}$ Edy M. Ya'kub, NU, Muhammadiyah, dan FPI, http://www.antaranews.com/berita/248702/nu-ahmadiyah-dan-fpi/diakses 16 Juli 2015.

25 Ancaman Perda Anti-Abmadiyah, http://www.tempo.co/read/fokus/2011/03/01/1761/Ancaman-Perda-Anti Ahmadiyah/diakses 16 Juli 2015.
} 
Ahmadiyah dan mendiskriminasi Ahmadiyah. ${ }^{26}$ Peraturan semacam ini mampu menjadi pintu masuk bagi daerah-daerah lain di Indonesia untuk mengadopsi peraturan yang mempunyai substansi sama dengan Surat Keputusan Gubernur No.188/94/KPTS/013/2011.

Tanggapan terhadap penerbitan SK anti-Ahmadiyah di Jawa Timur tidak berhenti sampai di situ. Sejumlah organisasi yang tergabung dalam Jaringan Masyarakat Sipil untuk Perlindungan Warga Negara meminta pemerintah untuk mencabut SK tersebut karena dikhawatirkan dapat meningkatkan eskalasi kekerasan dan persekusi terhadap Ahmadiyah. ${ }^{27}$ Ketua Yayasan Pengurus YLBHI menambahkan bahwa SK Gubernur No. 188/94/KPTS/013/2011 merupakan kebijakan daerah yang melanggar ketentuan tata cara perundang-undangan. Surat Keputusan yang dikeluarkan oleh Gubernur Jawa Timur itu tidak memperhatikan partisipasi publik, bahkan Ahmadiyah tidak pernah dimintai penjelasan maupun klarifikasi terkait Surat Keputusan tersebut. ${ }^{28}$ Selain itu, Direktur LBH Jakarta juga menyatakan permintaan kepada pemerintah untuk segera melakukan kajian terhadap peraturan daerah anti-Ahmadiyah di beberapa daerah termasuk Jawa Timur. Peraturan tersebut dianggap sebagai peraturan yang terkesan prematur karena prosesnya mendahului proses peradilan dan menuduh konflik yang terjadi disebabkan oleh Ahmadiyah. ${ }^{29}$

Menjawab berbagai protes dari berbagai pihak tentang penerbitan SK Gubernur No.188/94/KPTS/013/2011, pemerintah Jawa Timur mengupayakan untuk menjaga ketertiban umum terkait kasus yang terjadi pada Ahmadiyah. Pada prinsipnya, pemerintah melarang segala aktivitas yang dapat menimbulkan kecemburuan umat Islam lainnya. ${ }^{30}$ Selain melarang aktivitas keagamaan yang mampu mengganggu ketertiban umum, pemerintah mengaku tidak mempunyai wewenang untuk melarang ritual keagamaan terkait akidah Ahmadiyah. Pemerintah Jawa

\footnotetext{
${ }^{26} \mathrm{Ibid}$.

27 Regulasi Lokal tentang Ahmadiyah ditentang, http://www.beritasatu.com/nasional/9106regulasi-lokal-tentang-ahmadiyah-ditentang.html/diakses 16 Juli 2015.

28 Ibid.

${ }^{29}$ Ibid.

30 Ancaman Perda Anti-Ahmadiyah, http://www.tempo.co/read/fokus/2011/03/01/1761/Ancaman-Perda-Anti Ahmadiyah/diakses 16 Juli 2015.
} 
Timur menegaskan bahwa Surat Keputusan Gubernur No.188/94/KPTS/013/2011 dimaksudkan untuk meredamkan potensi kemarahan umat Islam atau pencegahan terhadap konflik sosial. ${ }^{31}$ Kebijakan yang diambil Gubernur Jawa Timur merupakan kebijakan yang tepat dan tidak menyalahi aturan HAM. Alasan pelarangan aktivitas keagamaan Ahmadiyah adalah karena para pendukung SK Gubernur khawatir ajaran Ahmadiyah masih tetap menyebar meskipun dibubarkan. $^{32}$

\section{Respons dan Pembatasan Internal Ahmadiyah Jawa Timur}

Sejak pemberlakuan Surat Keputusan Gubernur No.188/94/KPTS/013/2011, kegiatan Ahmadiyah sering kali dibatasi bahkan diawasi oleh aparat. Kelompok yang berjumlah sekitar 1000 jemaat $^{33}$ di Jawa Timur ini merasakan dampak dari adanya SK tersebut. Selain pembatasan aktivitas keagamaan, kegiatan sosial kemanusiaan yang rutin diadakan oleh Ahmadiyah juga mendapat pengawasan ketat dari aparat. Pemasangan papan nama organisasi juga turut dilarang sejak adanya SK yang terbit pada 28 Februari 2011. Salat Jumat yang merupakan kewajiban bagi Muslim juga menjadi salah satu larangan pemerintah kepada Ahmadiyah. ${ }^{34}$

Ahmadiyah menganggap bahwa Surat Keputusan Gubernur itu bukan merupakan win-win solution, karena pada akhirnya Ahmadiyah menjadi pihak yang lebih banyak ditekan. ${ }^{35}$ Terlebih, isi dari SK Gubernur telah mereduksi muatan dari SKB yang sebenarnya tidak melarang aktivitas Ahmadiyah seluruhnya. Menurutnya, dalam tataran hukum jika ada peraturan yang bertolak belakang dengan peraturan yang lebih tinggi, maka peraturan tersebut batal hukum. ${ }^{36}$ Selain itu, dalam SK

\footnotetext{
31 SK Pelarangan Abmadiyah: Gubernur Jatim Siap Hadapi Gugatan Ahmadiyah, http://www.voa-islam.com/read/indonesiana/2011/03/03/13585/sk-pelaranganahmadiyah-gubernur-jatim-siap-hadapi-gugatan/diakses 17 April 2015. 32 Ibid.

33 Angka ini berdasarkan pada Basuki, Wawancara, Surabaya, 18 Juni 2015.

${ }^{34}$ Ibid.

35 Ibid.

${ }^{36}$ Ibid.
} 
Gubernur pelarangan aktivitas tidak ditunjukkan secara detail sebagaimana dalam SKB. Ambiguitas inilah yang menjadikan kelompok Ahmadiyah sering kali menjadi sasaran diskriminasi. ${ }^{37}$

Ahmadiyah berpendapat bahwa sosialisasi SKB perlu dilakukan secara maksimal karena hal tersebut merupakan salah satu upaya pemahaman kepada masyarakat dalam menyikapi peraturan-peraturan daerah yang menginduk pada SKB, khususnya SK Gubernur Jawa Timur No.188/94/KPTS/013/2011. Di dalam SKB, larangan hanya tertuju pada penyebaran paham kesesatan yaitu mengakui adanya Nabi setelah Nabi Muhammad. Sedangkan dalam SK Gubernur, larangan bersifat global pada aktivitas yang dapat memicu terganggunya ketertiban umum dan tidak dijelaskan dengan poin-poin penjelas. ${ }^{38}$

Menurut Ahmadiyah, SK Gubernur telah menyalahi konstitusi karena telah bertentangan dengan SKB. Jika di level nasional tidak ada larangan yang spesifik terkait urusan agama, maka pemerintah daerah tidak boleh menerbitkan peraturan atau kebijakan yang bertentangan dengan hal tersebut. Meskipun kebijakan tentang otonomi daerah sudah berlaku, namun hal tersebut tidak serta merta melegalkan pemerintah daerah untuk mengatur semua urusan masyarakat, khususnya agama. Agama merupakan salah satu kewenangan pemerintah pusat. ${ }^{39}$

Pengaruh dari SK Gubernur terhadap pola pikir masyarakat cukup tajam. Identitas Ahmadiyah lebih banyak dikenal dengan paham tentang adanya Nabi setelah Nabi Muhammad. Padahal menurut Ahmadiyah, banyak hal yang seharusnya masyarakat pahami selain keyakinan teologis mereka. Ahmadiyah mempunyai lembaga sosial yang memiliki peran yang tidak sedikit terhadap musibah yang kerap terjadi di Indonesia. ${ }^{40}$ Sejak terbitnya SK Gubernur No.188/94/KPTS/013/2011, masyarakat menafsirkan bahwa Ahmadiyah merupakan kelompok sesat yang saat ini sudah dilarang keberadaannya di Indonesia. Anggapan tersebut menyebabkan berbagai tindakan pelarangan bahkan tindakan anarkis oleh kelompok radikal. Selain dari SK Gubernur, pola pikir

\footnotetext{
${ }^{37}$ Ibid.

${ }^{38}$ Ibid.

${ }^{39}$ Ibid.

${ }^{40}$ Ibid.
} 
masyarakat tentang Ahmadiyah juga dibentuk oleh produk di luar hukum yaitu fatwa MUI. Ahmadiyah beranggapan bahwa MUI merupakan organisasi kemasyarakatan sebagaimana posisi Ahmadiyah di Indonesia. Fatwa MUI bukan merupakan produk hukum yang isinya harus dipatuhi oleh masyarakat umum. Jika MUI sebagai ormas mempunyai hak untuk menerbitkan fatwa, Ahmadiyah juga merasa punya hak yang sama terkait penerbitan fatwa. Selain itu, jika fatwa MUI mampu menjadi rujukan bagi masyarakat untuk menindak suatu hal, maka Ahmadiyah merasa perlu untuk duduk dalam jajaran MUI di Indonesia. Mereka menganggap bahwa apa yang difatwakan oleh MUI bukan sebagaimana Ahmadiyah sebenarnya. Fatwa yang menyangkut masalah teologis suatu aliran, harus berdasarkan dari sumber utama, bukan dari sumber sekunder atau bahkan sumber yang belum diketahui bobotnya. ${ }^{41}$

Sebagai respons dari diskriminasi terhadap kelompok mayoritas, minoritas Ahmadiyah menerapkan beberapa pembatasan internal sebagai wujud eksistensi kelompok tersebut. Secara teologis, mereka menerapkan sistem ikrar baiat dengan 10 syarat yang harus dipenuhi ketika menjadi seorang Ahmadiyah. Sepuluh syarat baiat tersebut merupakan cerminan sederhana dari ajaran Alquran dan hadis. ${ }^{42}$ Ahmadiyah mempunyai mubalig yang dikhususkan untuk membimbing maupun mengawasi anggotanya agar selalu berada dalam koridor 10 syarat baiat. Mubalig tersebut dididik dengan kurikulum internal Ahmadiyah, yang pada akhirnya diperintahkan untuk mengabdi kepada Ahmadiyah.

Dalam kehidupan sosial, Ahmadiyah membatasi kelompoknya dengan menyebut kelompok non-Ahmadiyah sebagai ghayr-Aḅmadî. Ghayr-Ahmadî berarti bukan seorang anggota Ahmadiyah atau orang yang belum melakukan baiat masuk ke Jemaat Ahmadiyah. Sebutan tersebut menurut Ahmadiyah tidak sama dengan sebutan kafir. Bagi Ahmadiyah, sebutan kafir hanya untuk orang yang tidak bersyahadat. Tidak ada sebutan kafir hanya karena tidak percaya dengan Mirza Ghulam Ahmad. Namun, karena orang-orang ghayr-Aḅmadî mulai memfatwakan kafir pada

${ }^{41}$ Ibid.

${ }^{42}$ Ibid. 
Ahmadiyah, maka menurutnya yang menjadi kafir adalah ghayr-Aḥmadî tersebut. ${ }^{43}$

Sebagai dampak dari fatwa kafir dari ghayr-Aḥmadî terhadap Ahmadiyah, telah menyebabkan orang-orang Ahmadiyah menolak bermakmum dengan ghayr-Aḥmadî. Selain itu, mereka juga membatasi jemaatnya agar menikah dengan sesama anggota Ahmadiyah. Larangan tersebut bertujuan menyelamatkan rumah tangga keluarga Ahmadiyah agar selalu tercipta keharmonisan dalam rumah tangga. ${ }^{44}$ Dalam menerapkan pernikahan antar-anggota Ahmadiyah, organisasi Ahmadiyah mempunyai sistem perjodohan internasional. Hal tersebut bertujuan untuk meminimalkan pernikahan dengan ghayr-Aḥmadî. ${ }^{45}$

\section{Perspektif External Protection dan Internal Restriction}

Surat Keputusan Gubernur No.188/94/KPTS/013/2011 yang terbit pada 28 Februari 2011 merupakan salah satu upaya perlindungan pemerintah terhadap Ahmadiyah. ${ }^{46}$ Surat Keputusan tersebut berupaya untuk melindungi kelompok minoritas Ahmadiyah di Jawa Timur dari serangan massa atau organisasi kemasyarakatan yang bertentangan paham dengan Ahmadiyah. Dalam pasal yang tertera pada SK Gubernur tersebut, Pemerintah hendak membatasi segala kegiatan keagamaan yang mampu memicu gangguan ketertiban umum, diantaranya adalah memasang papan nama organisasi, menggunakan atribut Ahmadiyah, menyebarkan ajaran Ahmadiyah baik lisan, tulisan, maupun media elektronik.

Dari beberapa organisasi kemasyarakatan yang menganggap bahwa Ahmadiyah merupakan ajaran yang sesat, meminta kepada pemerintah untuk membubarkan aliran keagamaan yang dibawa dari

\footnotetext{
${ }^{43}$ Syamsir Ali, Madu Abmadiyah untuk Para Penghujat (Ttp: Wisma Damai, 2011), 29.

${ }^{44}$ Saleh A. Nahdi, Kiat-Kiat Tabligh yang Efektif (Jakarta: Yayasan Radja Press, 1994), 7879 .

45 Ibid.

46 Serikat Pengajar Hak Asasi Manusia Seluruh Indonesia (SEPAHAM), Melindungi Korban Bukan Membela Pelaku, Kertas Posisi atas dikeluarkannya Sejumlah Produk Hukum Daerah yang Melarang Aktivitas Jemaat Ahmadiyah Indonesia, Maret 2011.
} 
Qadian, India. Di beberapa daerah, sering kali kelompok Ahmadiyah menjadi sasaran kelompok Islam radikal dengan berbagai dalih, dari mulai produk hukum SKB, SK, ataupun perda yang berisi tentang pembekuan organisasi Ahmadiyah di Indonesia, sampai pada fatwa yang terbit dari beberapa organisasi masyarakat seperti MUI pada tahun 1980 dan 2005. Peraturan-peraturan maupun fatwa yang diterbitkan untuk Ahmadiyah menjadi alat legitimasi bagi individu maupun kelompok radikal untuk mempersekusi minoritas Ahmadiyah.

Idealnya, perlindungan eksternal sebagaimana istilah yang dijelaskan oleh Kymlicka, merupakan usaha pemerintah untuk mengupayakan suatu kelompok kecil agar tidak tertindas oleh kelompok lain yang lebih besar. Namun, dalam upaya perlindungan eksternal tidak harus menimbulkan ketidakadilan dari dampak perlindungan tersebut, baik untuk masyarakat dominan maupun minoritas. ${ }^{47}$ Dalam praktik penerbitan SK Gubernur, pemerintah memang mengupayakan untuk memberi perlindungan Ahmadiyah terhadap kelompok yang secara langsung maupun tidak berlawanan dengan minoritas Ahmadiyah. Namun, pasal-pasal yang terdapat dalam SK Gubernur mencerminkan pembatasan terhadap minoritas Ahmadiyah. Apalagi dalam proses pembuatan maupun penerbitan, Ahmadiyah tidak pernah sama sekali diundang untuk sekedar audiensi maupun klarifikasi atas suatu hal yang diperkarakan, seperti ajaran sesat yang dimaksud dalam kelompok antiAhmadiyah.

Selain perkara SK Gubernur, yang menjadi dasar kelompokkelompok Islam arus-utama dalam menyerang Ahmadiyah adalah fatwa MUI. Jika fatwa MUI dijadikan dasar sebagai bahan rujukan bagi masyarakat untuk menindak suatu hal, maka sudah seharusnya MUI mengundang setiap perwakilan dari semua kelompok untuk dapat merumuskan fatwa secara objektif. Jika fatwa yang dikeluarkan adalah tentang akidah Ahmadiyah, maka Ahmadiyah seharusnya diberikan kesempatan untuk menjelaskan tentang tafsir yang tidak dipahami oleh sebagian besar umat Islam di Indonesia.

47 Will Kymlicka, Kewargaan Multikultural, 54. 
Dalam penerapan perlindungan eksternal tidak terlepas dengan hak-hak perwakilan khusus. Hak inilah yang mampu menciptakan keseimbangan dalam menentukan suatu hukum. Ahmadiyah perlu diberikan ruang dalam keanggotaan MUI atau bahkan badan legislatif sehingga keputusan-keputusan yang diambil oleh pemerintah tidak merugikan kelompok Ahmadiyah. Perlindungan eksternal seharusnya bertujuan untuk menciptakan keadilan dan bahkan membantu kelompok-kelompok yang berbeda dengan mengurangi dominasi masyarakat terhadap minoritas. ${ }^{48}$ SK Gubernur sebenarnya tidak layak disebut sebagai perlindungan karena dalam penerapannya Ahmadiyah bahkan menerima ketidakadilan dengan pembatasan-pembatasan yang ditetapkan. Akan disebut sebagai perlindungan jika SK Gubernur mampu menciptakan keadilan dengan mengurangi kerentanan Ahmadiyah terhadap masyarakat luas. Adanya SK Gubernur bahkan menjadikan kelompok Ahmadiyah menjadi termarjinalkan baik dalam hubungan sosial maupun hukum. Selain itu, diskriminasi masyarakat luas terhadap Ahmadiyah semakin tajam ketika terbit SK Gubernur atau perda-perda tentang Ahmadiyah, misalnya pelarangan salat Jumat terhadap warga Ahmadiyah di Surabaya.

Selain hak perwakilan khusus, Ahmadiyah juga memungkinkan untuk meminta hak polietnis sebagai cara penerapan perlindungan eksternal. Ahmadiyah perlu untuk meminta perlindungan terkait aset yang dimiliki seperti sekolah, perguruan tinggi, dan lembaga-lembaga lain yang dimiliki. Selain perlindungan, adanya pengakuan negara terhadap kurikulum yang dibuat juga merupakan hal yang penting sebagai salah satu penerapan hak polietnis. Perlindungan tersebut bukan merupakan suatu hal yang mustahil karena hal tersebut memungkinkan diterapkan pada organisasi kemasyarakatan yang lain, seperti NU dan Muhammadiyah. Tidak ada pengecualian terkait hak tersebut, karena posisi antara Ahmadiyah dengan ormas lain adalah setara.

Perlindungan eksternal bertujuan untuk melindungi kelompok kecil terhadap keputusan-keputusan yang dibuat oleh kelompok lain yang lebih besar seperti fatwa MUI. Selain terlindungi dari dampak keputusan kelompok eksternal, Ahmadiyah juga berhak atas aturan-aturan dari

${ }^{48}$ Kymlicka dan Marin, Liberalisme and Minority Rights, 137. 
pemerintah yang tidak diskriminatif. Tujuan-tujuan ini tampaknya tidak tercermin dalam SK Gubernur No.188/94/KPTS/013/2011. Surat Keputusan tersebut bahkan menjadikan Ahmadiyah semakin terintimidasi oleh kelompok lain bahkan oleh aparatur negara sendiri.

Sebagai respons atas perlindungan yang membatasi gerak Ahmadiyah, Ahmadiyah juga melakukan pembatasan internal terhadap anggotanya. Bentuk pembatasan tersebut adalah dengan perintah baiat sebelum masuk ke dalam Jemaat Ahmadiyah. Selain itu, Ahmadiyah juga membatasi kelompoknya untuk tidak menikah dengan ghayr-Aḥmadî. Sikap eksklusif yang diterapkan oleh Ahmadiyah inilah yang disebut oleh Kymlicka sebagai pembatasan kebudayaan kelompok atas nama solidaritas kelompok. ${ }^{49}$

Pembatasan internal yang dilakukan Ahmadiyah merupakan syarat keanggotaan yang diajukan oleh Ahmadiyah terhadap anggotanya. Namun, pembatasan tersebut tidak sampai menggunakan kebijakan pemerintah sehingga melalaikan hak-hak individu dalam kelompok Ahmadiyah. Namun, karena loyalitas orang-orang Ahmadiyah terhadap organisasinya, menjadikan kelompok ini selalu bertahan dan hanya sedikit anggota Ahmadiyah yang memutuskan untuk keluar dari Jemaat tersebut. Mereka meyakini bahwa siapa pun yang menghalangi jalan untuk melakukan misinya, maka Allah akan menyingkirkannya. ${ }^{50}$

Pelarangan untuk menikah dengan ghayr-Aḥmadî bukan berarti pengharaman atau bahkan menjadikan pernikahan tidak disahkan oleh negara, melainkan upaya tersebut bertujuan untuk melindungi kelompok Ahmadiyah sehingga mampu untuk membangun rumah tangga yang harmonis. ${ }^{51}$ Pelarangan terkait berjamaah dengan ghayr-Ahmadî juga merupakan salah satu upaya untuk melindungi kelompoknya dari niat buruk orang yang membenci Ahmadiyah.

\footnotetext{
${ }^{49}$ Ibid.

50 Mirza Bashiruddin Mahmud Ahmad, Da'watul Amir (ttp: Jemaat Ahmadiyah Indonesia, 1989), 228.

${ }^{51}$ Syamsir Ali, Madu Abmadiyah untuk Para Penghujat, 47.
} 


\section{Penutup}

Surat Keputusan Gubernur No.188/94/KPTS/013/2011 secara substansial telah mencederai hak-hak dasar kelompok Ahmadiyah. Sebagai upaya perlindungan terhadap kelompok minoritas, SK ini justru semakin menempatkan kelompok Ahmadiyah dalam posisi yang rentan terhadap serangan kelompok mayoritas di luar Ahmadiyah. perlindungan dengan menerbitkan peraturan diskriminatif tersebut lebih layak disebut sebagai penindasan kelompok minoritas. Meskipun secara konstitusional negara menjamin kebebasan memeluk agama dan menjalankan ibadah, namun faktanya minoritas Ahmadiyah masih belum secara bebas mengamalkan dan mengembangkan agama dan keyakinan mereka. Ironisnya, munculnya perlakuan diskriminatif ini justru dilakukan oleh negara melalui penerbitan rangkaian peraturan yang kemudian menjadikan alat legitimasi bagi kelompok anti-Ahmadiyah untuk mempersekusi minoritas Ahmadiyah.

Di dalam internal kelompok Ahmadiyah, kelompok ini juga menerapkan pembatasan internal terhadap kelompoknya. Bentuk pembatasan tersebut adalah dengan 10 syarat baiat, pernikahan dengan sesama anggota Ahmadiyah, dan larangan bermakmum dengan orangorang ghayr-Aḥmadî. Pembatasan yang dilakukan oleh Ahmadiyah ini menjadi wajar karena hal ini bertujuan untuk mempertahankan eksistensi kelompok. Penerapan pembatasan ini tidak bertentangan dengan hak-hak individu kelompok Ahmadiyah karena tidak didukung instrumen hukum atau kebijakan pemerintah. Selain itu, pembatasan kelompok Ahmadiyah juga tidak menimbulkan provokasi untuk melawan pemerintah.

\section{Daftar Pustaka}

Ahmad, Mirza Bashiruddin Mahmud. Da'watul Amir. Ttp: Jemaat Ahmadiyah Indonesia, 1989.

Ahmad, Munawar. Candy's Bowl: Politik Kerukunan Umat Beragama di Indonesia. Yogyakarta: Suka Press, 2013.

Ali, Syamsir. Madu Ahmadiyah untuk Para Penghujat. Ttp: Wisma Damai, 2011. 
Almagor, Raphael Cohen. Democracy and Multiculturalism, Challenges to Democracy: Essays in Honour and Memory of Isaiah Berlin. London: Ashgate Publishing Ltd, 2000.

Ancaman Perda Anti-Abmadiyah, http://www.tempo.co/read/fokus/2011/03/01/1761/Ancaman-Perda-Anti-Ahmadiyah.

Bagir, Zainal Abidin. Telaah Kasus Ahmadiyah di Indonesia. Yogyakarta: Dokumen CRCS, 2011.

Burhani, Ahmad Najib. "Tiga Problem Dasar dalam Perlindungan Agama-Agama Minoritas di Indonesia”. Dalam Ma'arif, Vol. III, No. 1, 2012.

Edy M. Ya'kub, NU, Muhammadiyah, dan FPI, http://www.antaranews.com/berita/248702/nu-ahmadiyah-dan-fpi.

Human Right Watch. Atas Nama Agama: Pelanggaran terhadap Minoritas Agama di Indonesia (USA: Human Right Watch, 2013), 37; Lihat, Kontras, Pelanggaran HAM dan Pelanggaran HAM Berat dalam Kasus-Kasus Kebebasan Beragama Berkeyakinan dan Beribadab di Indonesia, 11-12.

Kymlicka, Will. Kewargaan Multikultural, terj. F. Budi Hardiman. Jakarta: LP3ES, 2002.

Kymlicka, Will and Marin, Rubio. "Liberalism and Minority Rights, An Interview". Dalam Ratio Juris, Vol. 12, No. 02. Cowley Road: Blackwell Publisher Ltd, 1999.

Keputusan Gubernur Jawa Timur Nomor 188/94/KPTS/013/2011 tentang Larangan Aktivitas Jemaat Ahmadiyah Indonesia (JAI) di Jawa Timur.

Keputusan Bersama Menteri Agama, Jaksa Agung, dan Menteri dalam Negeri dalam Negeri Republik Indonesia No. 3 Tahun 2008, Kep-033/A/JA/6/2008, No. 199 Tahun 2008.

Munarman: Abmadiyah Adu Domba Pemerintah, http://www.suaraislam.com/read/index/2223/Munarman--Ahmadiyah-AduDomba-Pemerintah. 
http://www.nu.or.id/a,public-m,dinamic-s,detail-ids,1-id,3548lang,idc, wartat,MUI+Dinilai+Telah+Jadi+Inspirator+Tindakan +Kekerasan-phpx.

Nahdi, Saleh A. Kiat-Kiat Tabligh yang Efektif. Jakarta: Yayasan Radja Press, 1994.

Nasution, Khoirudin. "Fatwa Majelis Ulama Indonesia (MUI): On Ahmadiyah". Dalam Millah Jurnal Studi Agama, Vol. 7, No. 2, 2008

O'Neill, Daniel I. Multicultural Liberals and the Rushdie Affair: A Critique of Kymlicka, Taylor, and Walzer. The Review Politics, Vol. 61, No. 02. Notre Dame: Cambridge University Press, 1999.

Regulasi Lokal tentang Ahmadiyah ditentang, http://www.beritasatu.com/nasional/9106-regulasi-lokaltentangahmadiyah-ditentang.html.

Ruhana, Akmal Salim. "Negara Sekuler Mengatur Agama: Studi Pengelolaan Kehidupan Keagamaan di Singapura dan Lesson Learned untuk Indonesia”. Dalam Dialog, Vol.VII, No.1, 2012.

Ruhana, Akmal Salim. Menguji Penanganan Ahmadiyah. Jakarta: Gaung Persada Press, 2009.

Serikat Pengajar Hak Asasi Manusia Seluruh Indonesia (SEPAHAM). Melindungi Korban Bukan Membela Pelaku. Kertas Posisi atas dikeluarkannya Sejumlah Produk Hukum Daerah yang Melarang Aktivitas Jemaat Ahmadiyah Indonesia, Maret 2011.

SK Pelarangan Ahmadiyah: Gubernur Jatim Siap Hadapi Gugatan Ahmadiyah, http://www.voa.islam.com/read/indonesiana/2011/03/03/135 85/sk-pelarangan-ahmadiyah-gubernur-jatim-siap-hadapigugatan/.

The Wahid Institute. Laporan Tabunan Kebebasan Beragama/Berkeyakinan dan Intoleransi 2014: Utang Warisan Pemerintahan Baru. Jakarta: The Wahid Institute, 2014. 